\title{
PRASANGKA KONFLIK \& KECEMBURUAN SOSIAL ANTARA PEKERJA CHINA DAN MASYARAKAT LOKAL DI PT. VIRTUE DRAGON NIKEL INDUSTRI SULAWESI TENGGARA
}

\author{
Aldilal $^{1}$, Andi Alimuddin Unde ${ }^{2}$, Jeanny Maria Fatimah ${ }^{3}$ \\ ${ }^{1}$ Program studi Ilmu Komunikasi Universitas Hasnuddin, aldilalkomunikasi@gmail.com \\ ${ }^{2}$ Departemen Ilmu Komunikasi Universitas Hasanuddin, Undealimuddin@yahoo.co.id \\ ${ }^{3}$ Departemen Ilmu Komunikasi Universitas Hasanuddin, jeannymaria@gmail.com
}

\begin{abstract}
Abstrak
Kedatangan tenaga kerja China di Sulawesi Tenggara telah menjadi problematika dikalangan masyarakat lokal yang selalu menjadi konflik antara pekerja China dan masyarakat lokal dimana mereka berinteraksi. Tujuan penelitian ini untuk mengetahui penyebab prasangka konflik dan kecemburuan sosial antara tenaga kerja China dan masyarakat lokal. Penelitian ini menggunakan metode kualitatif deskriptif, sampel penelitian di ambil dengan metode purposive sampling dan snowball sampling. Hasil penelitian menunjukkan penyebab prasangka konflik antara tenaga kerja China dan masyarakat lokal di Sulawesi Tenggara adalah adanya stereotype budaya negatif dan adanya ketidakberimbangan gaji karyawan antara pekerja China dan tenaga kerja lokal, juga dominan pekerja China yang menempati jabatan di perusahaan pertambangan telah memicu kecemburuan sosial dikalangan masyarakat lokal.
\end{abstract}

Kata kunci: Komunikasi antarbudaya, Konflik, Stereotype, Tenaga kerja asing

\section{Abstract}

The arrival of Chinese workers in Southeast Sulawesi has become problematic among local communities which has always been a conflict between Chinese workers and the local communities in which they interact. The purpose of this study is to find out the causes of conflict prejudice and social jealousy between Chinese labor and local communities. This study uses descriptive qualitative methods, research samples taken with purposive sampling methods, and snowball sampling. The results showed the cause of the prejudice conflict between The Chinese workforce and the local community in Southeast Sulawesi is the negative cultural stereotype and the inequality of employee salaries between Chinese workers and local workers, as well as dominant Chinese workers who occupy positions in mining companies, have fueled social jealousy among the local community.

Keywords: Interculture communication, Conflict, Stereotype, Foreign labor

\section{PENDAHULUAN}

Melihat fenomena keberadaan tenaga kerja China baik yang di sampaikan oleh berbagai media maupun informasi yang diketahui masyarakat tentang isu kedatangan dan keberadaan tenaga kerja asing (China) yang masuk dan bekerja di berbagai perusahaan di Indonesia telah memicu perhatian publik dalam beberapa tahun ini. Khususnya masyarakat di Sulawesi Tenggara jika dilihat dari data yang disampaikan tenaga kerja China di Sulawesi Tenggara sudah mencapai angka ribuan pekerja. Data yang dirilis pada tanggal 18 Februari 2019, oleh Saemu Alwi selaku kepala dinas tenaga kerja Sulawesi Tenggara mengatakan bahwa jumlah

SSN: 2355-0287, E-ISSN: 2549-3299 
orang asing yang bekerja di PT. Vitue Dragon Nickel Industri berjumlah 1452 pekerja.

Hadirnya tenaga kerja china khususnya di PT.Virtue Dragon Nickel Industri yang beroperasi di morosi, kabupaten konawe, Sulawesi Tenggara, terus menuai pro dan kontra, sebagian masyarakat lokal berharap mereka akan memberikan dampak yang bersifat Transfer Of Knowledge, Memberikan contoh yang baik tentang bagaimana skill dan standar kerja International agar tenaga kerja lokal bisa belajar banyak dari keberadaan mereka. Namun dengan keberadaan mereka juga membuat kekhawatiran warga lokal akan bahayanya jika terjadi konflik berkepanjangan karena keberadaan mereka bisa menimbulkan adanya kecemburuan sosial di masyarakat yang di akibatkan karena warga lokal masih banyak yang belum memiliki pekerjaan dan ini bisa berpotensi mengakibatkan kecemburuan sosial.

Tenaga kerja China yang memiliki latar belakang budaya dan juga bahasa yang berbeda dengan masyarakat setempat tentunya akan memiliki hambatan pekerja China dalam berkomunikasi saat mereka berada di lingkungan baru dimana pekerja China tinggal. Adanya hambatan komunikasi saat beradaptasi tentunya akan berpotensi terjadi kesalahpahaman bahkan terjadi konflik. Perbedaan budaya atau kebiasaan keseharian tenaga kerja china yang mereka terapkan di dalam keseharian di perusahaan tersebut juga akan memberikan hal yang belum tentu bisa secara langsung di terima di lingkungan antara tenaga kerja lokal yang bekerja di perusahaan tersebut sehingga bisa saja terjadi kesalahpahaman karena perbedaan budaya tersebut. Latar belakang pendidikan atau pengetahuan dan cara tenaga kerja china berpikir juga tidak secara langsung diterima dengan tenaga kerja lokal sehingga tidak menutup kemungkinan akan menimbulkan juga kesalahpahaman. Jika ini terus menerus terjadi tidak menutup kemungkinan akan terjadi chaos antara tenaga kerja China dan Tenaga kerja lokal di PT. Virtue Dragon Nickel Industry. Rintangan budaya adalah rintangan yang terjadi yang disebabkan karena adanya perbedaan norma, kebiasaan, dan nilainilai yang dianut oleh pihak-pihak yang terlibat dalam komunikasi (Cangara, 2002)

Aspek lainnya yang sering menjadi permasalahan yang mengakibatkan konflik dalam komunikasi lintas budaya adalah sering munculnya pemikiranpemikiran yang bersifat stereotype, prasangka, serta ketidakpastian dan kecemasan terhadap budaya baru. Stereotip adalah cara pandang atau persepsi orang tertentu terhadap suatu objek dan dengan dasar tersebut dia kemudian menciptakan nilai atau standar pada suatu hal (Lippmann, 2017). Stereotip dapat di artikan sebagai suatu anggapan dari orang lain yang kaku dan seakan-akan tidak berubah terhadap suatu kelompok yang lain. Dalam kamus psikologi definisi stereotip adalah persepsi terhadap suatu objek, individu maupun kelompok yang bersifat kaku atau tidak bisa diubah (Chaplin, 2004)

Hal tersebut tentunya akan memberi dampak bagi individu yang memasuki budaya baru untuk mencari tahu bagaimana karakteristik budaya baru tersebut, baik dari kebiasaankebiasaan, Bahasa, adat istiadat, serta makna symbol-simbol yang digunakan oleh budaya tersebut. Bahasa merupakan salah satu faktor yang menyebabkan kurang efektifnya interaksi yang terjadi dalam komunikasi antarbudaya. Kurangnya pemahaman mengenai bahasa yang berbeda dapat menimbulkan kesalahpahaman dan perasaan tidak nyaman, dan akibat dari kesalahpahaman tersebut banyak kita jumpai konflik-konflik yang terjadi sebagai akibat dari etnosentrisme. Ketika kita berkomunikasi dengan orang-orang lain, kita dihadapkan dengan Bahasa-bahasa, aturan-aturan, dan nilai-nilai yang berbeda. Sulit bagi 
kita untuk memahami komunikasi mereka bila kita etnosentrik. Menurut William G. Sumner etnosentrisme adalah memandang segala sesuatu dalam kelompok sendiri sebagai pusat segala sesuatu itu, dan hal-hal lainnya diukur dan dinilai berdasarkan kelompoknya ("William B. Gudykunst, Young Yun Kim (Eds.): Methods for Intercultural Communication Research, International and Intercultural Communica Tion Annual, Vol. 7," 1985)

Terlepas dari problematika yang terjadi antara tenaga kerja china dan masyarakat local di Sulawesi tenggara tidak bisa di pungkiri jika faktor kekuasaan dan ekonomi sejak lama telah menjadi penyebab hadirnya konflik antara masyarakat pribumi dan orang asing. Khususnya di Sulawesi tenggara kehadiran pekerja asing secara terus menerus membuat kekhawatiran masyarakat lokal akan persaingan kerja. Hal tersebut semakin meningkatkan kekhawatiran dengan semakin banyaknya masyarakat yang tidak memiliki kerja.

Dari pemaparan diatas, penulis mencoba menganalisis lebih dalam prasangka konflik dan kecemburuan sosial antara pekerja China dan masyarakat lokal di Sulawesi tenggara. Penelitian ini juga diharapkan bisa menjadi acuan penanganan konflik yang sering terjadi antara pekerja china dan pekerja lokal di Sulawesi tenggara, serta penulis juga mengharapkan penelitian ini bisa menjadi acuan para akademis terhadap penanganan konflik.

\section{KAJIAN LITERATUR}

Komunikasi merupakan alat untuk membentuk identitas dan juga mengubah mekanisme. Identitas seseorang dibentuk saat berinteraksi sosial dengan orang lain. Orang tersebut mendapatkan pandangan serta reaksi orang lain dalam interaksi sosial dan sebaliknya, memperlihatkan rasa identitas dengan cara orang lain mengekspresikan diri dan merespons orang lain (Littlejohn \& Foss, 2009)
Dalam kehidupan sehari-hari, tidak peduli dimana berada, manusia selalu berinteraksi dengan orang-orang tertentu yang berasal dari kelompok, ras, etnik, atau budaya lain. Berinteraksi atau berkomunikasi dengan orang-orang yang berbeda kebudayaan merupakan pengalaman baru yang selalu dihadapi. Manusia tidak bisa dikatakan berinteraksi sosial kalua dia tidak berkomunikasi dengan cara atau melalui pertukaran informasi, ide-ide, gagasan, maksud serta emosi yang dinyatakan dalam simbol-simbol dengan orang lain (Alo liliweri, 2001).

Budaya adalah suatu konsep yang membangkitkan minat. Secara formal budaya didefinisikan sebagai tatanan pengetahuan, pengalaman, kepercayaan, nilai, sikap, makna, hirarki, agama, waktu, peranan, hubungan ruang, konsep alam semesta, objek-objek materi dan milik yang diperoleh sekelompok besar orang dari generasi ke generasi melalui usaha individu dan kelompok (Mulyana \& Rakhmat, 2010).

Budaya dan komunikasi tidak dapat dipisahkan, karena budaya tidak hanya menentukan siapa yang bicara dengan siapa, tentang apa, dan bagaimana orang menyandi pesan, makna yang dimiliki untuk pesan, dan kondisi-kondisinya utnuk mengirim, memperhatikan dan menafsirkan pesan. Sebenarnya seluruh perbendaharaan perilaku kita sangat bergantung pada budaya tempat kita dibesarkan. Konsekuensinya, budaya merupakan landasan komunikasi. Bila budaya beraneka ragam, maka beraneka ragam pula praktik-praktik komunikasi (Mulyana \& Rakhmat, 2010).

Istilah antarbudaya pertama kali diperkenalkan oleh Edward T. Hall pada tahun 1959, tetapi Hall tidak menerangkan pengaruh perbedaan budaya terhadap proses komunikasi antarpribadi. Selanjutnya, David K. berlo melalui bukunya The Process of communication (An Introduction to Theory and Practice) pada tahun 1960 menjelaskan perbedaan antarbudaya dalam berkomunikasi antar orang yang

SSN: 2355-0287, E-ISSN: 2549-3299 
memiliki budaya yang berbeda (Alo liliweri, 2001). Menurut Liliweri Komunikasi antarbudaya adalah komunikasi antarpribadi yang dilakukan oleh komunikator dan komunikan yang berbeda budaya, bahkan dalam satu bangsa sekalipun.

Konflik merupakan perbedaan atau pertentangan antar individu atau kelompok sosial yang terjadi karena perbedaan kepentingan, serta adanya usaha memenuhi tujuan dengan jalan menentang pihak lawan disertai dengan ancaman atau kekerasan (Soerjono Soekanto, 2006).

\begin{tabular}{llr}
\multicolumn{1}{c}{ Dalam Kamus Besar } & Bahasa \\
Indonesia & yang & disusun \\
Poerwadarminta, konflik & berarti \\
pertentangan atau percekcokan.
\end{tabular}
Pertentangan sendiri muncul ke dalam bentuk pertentangan ide maupun fisik antara dua belah pihak berseberangan (Susan, 2009).

\section{Teori konflik Segitiga Abc}

Johan Galtung menawarkan model segitiga, menurutnya konflik dapat dilihat sebagai sebuah segitiga, dengan notasi kontradiksi (C), Sikap (A), dan perilaku (B) pada puncak-puncaknya.

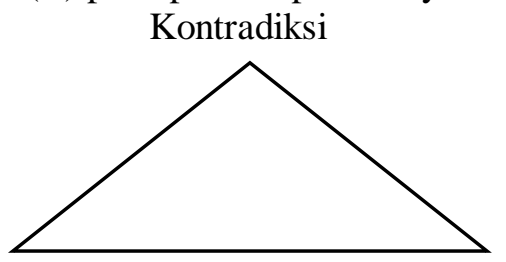

Sikap

Perilaku

Pertama, kontradiksi merujuk pada dasar situasi konflik, yang termaksud ketidakcocokan tujuan yang ada atau yang dirasakan oleh pihak-pihak yang bertikai yang disebabkan oleh apa yang dinamakan "ketidakcocokan antara nilai sosial dan struktur sosial". Dalam sebuah konflik yang asimetris, kontradiksi ditentukan oleh pihak-pihak yang bertikai, hubungan mereka dan benturan kepentingan inheren antara mereka dalam berhubungan.

Kedua, sikap. Yang dimaksud dengan sikap, termaksud persepsi, dari pihak-pihak yang bertikai. Sikap ini bisa positif atau negatif. Pada umumnya sikap negatif ada dalam konflik berbasis kekerasan di mana pihak-pihak yang bertikai cenderung mengembangkan stereotip negatif yang merendahkan pihak lain, sikap seperti ini seringkali dipengaruhi oleh emosi seperti ketakutan, kemarahan, kepahitan dan kebencian.

Ada beberapa cara resolusi konflik yang digunakan dalam proses penyelesaian konflik. Menurut Johan Galtung dalam (Putra, 2009), konflik dapat dicegah atau diatur jika pihakpihak yang berkonflik dapat menemukan cara atau metode menegosiasikan perbedaan kepentingan dan menyepakati aturan main untuk mengatur konflik.

Menurut pandangan Galtung (Galtung, 1969), resolusi konflik di bagi pada tiga tahapan yaitu peacemaking, peacekeeping, dan peace building.

1. Peacemaking merupakan sebuah strategi upaya dalam mengakhiri sebuah kekerasan penyebab konflik dengan cara membangun jembatan komunikasi antara pihak yang bertikai misalnya pengadaan sebuah perjanjian tertulis yang melibatkan mediator.

2. Peacekeeping adalah proses penjagaan keamanan dengan pengakuan masing-masing pihak terhadap perjanjian dan berusaha untuk selalu menjaganya sebagai sebuah perisai dalam penyelesaian konflik yang terjadi selanjutnya.

3. Peace building adalah proses pengimplementasian perubahan atau rekonstruksi sosial, politik maupun ekonomi demi tercapainya sustainable peace.

\section{METODE PENELITIAN}

\section{Pendekatan dan Jenis Penelitian}

Penelitian ini menggunakan pendekatan kualitatif deskriptif yaitu untuk menggambarkan suatu fenomena sosial. Penelitian ini akan mendeskripsikan

SSN: 2355-0287, E-ISSN: 2549-3299 
realitas sosial yang ada dimana penulis melakukan pengamatan secara langsung di lokasi penelitian. Pendekatan kualitatif digunakan untuk memahami interaksi sosial serta dengan metode wawancara mendalam diharapkan dapat diketahui bagaimana prasangka konflik dan kecemburuan social antara pekerja China dan pekerja lokal di Sulawesi tenggara.

\section{Lokasi penelitian}

Penelitian ini dilaksanakan di PT. VDNI (Virtual Dragon Nickel Industri) dimana pekerja asing china bekerja di perusahaan tersebut, meskipun demikian, waktu dan tempat penelitian di kondisikan dengan jadwal dan keinginan subjek penelitian. Alasan representatif memilih PT. VDNI (Virtual Dragon Nickel Industri) karena di perusahaan tersebut terdapat pekerja asing China dan jumlahnya paling banyak dari perusahaan lain sehingga dianggap mampu memberikan informasi penelitian.

\section{Jenis dan Sumber Data}

Penelitian ini menggunakan dua jenis data yaitu:

1. Data primer adalah data yang digunakan secara langsung dengan menggunakan wawancara terhadap informan tentang bagaimana prasangka konflik dan kecemburuan social antara pekerja China dan pekerja lokal di Sulawesi Tenggara

2. Data sekunder adalah data yang diperoleh melalui kajian pustaka, dokumen-dokumen, hasil penelitian yang relevan dan khususnya data yang memiliki hubungannya dengan penelitian

\section{Informan Penelitian}

Sampel pada riset kualitatif disebut infoman atau subjek riset, yaitu orangorang dipilih untuk diwawancarai atau di observasi sesuai tujuan riset. Disebut subjek riset bukan objek karena infoman diangap akiif mengkonstruksi realitas, bukan sekedar objek yang hanya mengisi kuisioner (Kriyantono, 2006). Dalam penelitian ini teknik sampling yang digunakan adalah Purposive sampling dan Snowball Sampling. Purposive Sampling yaitu teknik pengambilan sumber data dengan pertimbangan tertentu, seseorang atau sesuatu diambil sebagai sampel dengan pertimbangan peneliti menganggap bahwa yang bersangkutan mengetahui dan memahami betul inti permasalahan yang sedang diteliti, sedangkan Snowball Sampling adalah teknik penentuan sampel yang pada awalnya jumlahnya kecil kemudian bertambah besar (Sugiyono, 2011). Dengan purposive sampling dan snowball sampling maka peneliti mengambil informan dari tenaga kerja China dan pekerja lokal yang berada di PT. Virtue Dragon Nikel Industri dengan pertimbangan pekerja China dan pekerja lokal yang melakukan interaksi sosial.

Dalam penelitian kualitatif, sampel sumber data yang dikemukakan masih bersifat sementara namun demikian pembuat proposal perlu menyebutkan siapa-siapa yang kemungkinan akan digunakan sebagai sumber data. Berdasarkan penjelasan diatas maka peneliti menyebutkan siapa-siapa saja yang akan menjadi sampel sumber data penelitian ini, Subjek penelitian ini yaitu pimpinan/HRD, tenaga kerja asing, berjenis kelamin laki-laki dengan rentan usia antara 20-40 tahun yang telah bekerja selama 6 bulan-1 tahun. Dengan pertimbangan telah melakukan adaptasi komunikasi dengan tenaga kerja lokal, dan Tenaga kerja lokal berjenis kelamin laki-laki dengan rentan usia antara 20-40 tahun yang telah bekerja selama 6 bulan1 tahun di PT. VDNI (Virtual dragon Nickel Industri) di morosi, kabupaten Konawe, Sulawesi Tenggara.

\section{Teknik Pengumpulan Data}

Teknik pengumpulan data dilakukan dengan dua aspek yakni data Primer dan data sekunder.

1. Data primer ini diperoleh melalui penelitian lapangan yang langsung menemui para 
informan dan dilakukan dengan dua cara yakni Observasi adalah suatu teknik pengumpulan data yang dilakukan Dengan jalan mengamati secara langsung objek penelitian disertai dengan pencatatan yang diperlukan dan Wawancara mendalam (in-depth interview) yakni dengan menggunakan pedoman pertanyaan terhadap subjek penelitian dan informan yang dianggap dapat memberikan penjelasan mengenai bagaimana resolusi konflik dan rintangan komunikasi lintas budaya yang terjadi di PT. Viertue Dragon Nikel Industri. Peneliti selalu berperan penting dalam mengedepankan prinsip kesukarelaan informan dalam memberikan data yang di perlukan.

2. Data sekunder yaitu pengumpulan data jenis ini dilakukan dengan menelusuri bahan bacaan berupa jurnaljurnal, buku, internet dan berbagai hasil penelitian terkait.

\section{Teknik Analisis Data}

Data yang akan diperoleh di lapangan, dianalisis dalam bentuk deskriptif kualitatif, dengan tujuan mendeskripsikan hal-hal penelitian yang selanjutnya, menganalisis data dengan cara interpretative understanding maksudnya yaitu penulis melakukan penafsiran data dan fakta yang ada kaitannya dengan permasalahan penelitian. Dalam Penelitian ini analisis data menggunakan komponen analisis data yang bertujuan mengatur urutan mengorganisasikan nya, dan mengkategorikan nya. Cara analisis data yang digunakan peneliti adalah model interaktif (Miles \& Huberman, 1992) didasarkan tiga proses yang berlangsung secara interaktif.

1. Pengumpulan dan pengambilan data dengan menelaah seluruh data yang tersedia dari berbagai sumber, yaitu wawancara, pengamatan yang sudah ditulis dalam catatan lapangan, dokumentasi pribadi, gambar, foto, dan sebagainya;

2. Reduksi data merupakan suatu bentuk analisis yang menajamkan, menggolongkan, mengarahkan, membuang yang tidak perlu dan mengorganisasi data dengan cara sedemikian rupa hingga kesimpulankesimpulan final nya dapat ditarik dan di verifikasi;

3. Sajian data (Data display) merupakan suatu rakitan organisasi informasi yang memungkinkan kesimpulan riset dilakukan. Dengan melihat sajian data, peneliti akan lebih memahami berbagai hal yang terjadi dan memungkinkan untuk mengerjakan sesuatu pada analisis ataupun tindakan lain berdasarkan pemahaman tersebut. Semuanya ini disusun guna merakit informasi secara teratur supaya mudah dimengerti;

4. Penarikan Kesimpulan (Conclusion Drawing) merupakan pola proses yang dapat dilakukan dari sajian data dan apabila kesimpulan kurang jelas dan kurang memiliki landasan yang kuat maka dapat menambahkan kembali pada reduksi data dan sajian data. Kesimpulan yang perlu di verifikasi, yang berupa suatu pengulangan dengan gerak cepat, sebagai pemikiran kedua yang melintas pada peneliti, pada waktu menulis dengan melihat kembali pada file note.

HASIL

Karakteristik dan Identitas Tenaga kerja China dan tenaga kerja lokal

Tenaga kerja china adalah individu yang merupakan warga negara asing yang berasal dari China yang bekerja di PT. Virtue Dragon Nickel Industri

SSN: 2355-0287, E-ISSN: 2549-3299 
(VDNI) yang beroperasi di morosi, kabupaten Konawe, provinsi Sulawesi tenggara. Sedangkan tenaga kerja lokal adalah individu yang merupakan warga negara indonesia juga sebagai warga lokal setempat yang bekerja di PT. Virtue Dragon Nikel Industri (VDNI).

Identitas Informan Tenaga kerja china \& Tenaga kerja lokal

Dalam penelitian ini ada 3 orang pekerja China \& 3 orang pekerja lokal, yang terdiri dari 2 orang perempuan dan 4 orang laki-laki. Pada saat ini mereka sedang bekerja di PT. Virtue Dragon Nickel Industri (VDNI) yang berada di Morosi kabupaten Konawe Sulawesi Tenggara.

Tabel 1. Data Tenaga Kerja China yang menjadi informan

\begin{tabular}{|c|c|c|c|c|c|}
\hline No & Nama & Negara & Usia & Pekerjaan & $\begin{array}{c}\text { Lama } \\
\text { menetap }\end{array}$ \\
\hline 1 & $\begin{array}{l}\text { Jiang } \\
\text { lilii }\end{array}$ & China & $\begin{array}{c}26 \\
\text { tahun }\end{array}$ & $\begin{array}{c}\text { Sekretaris } \\
\text { HRD }\end{array}$ & $\begin{array}{c}1,2 \\
\text { Tahun }\end{array}$ \\
\hline 2 & $\begin{array}{c}\text { Mr. } \\
\text { Chang }\end{array}$ & China & $\begin{array}{c}35 \\
\text { tahun }\end{array}$ & $\begin{array}{l}\text { Pengawas } \\
\text { Konstruksi }\end{array}$ & 2 tahun \\
\hline 3 & $\begin{array}{l}\text { Mr. } \\
\text { Tsun }\end{array}$ & China & $\begin{array}{c}37 \\
\text { tahun }\end{array}$ & $\begin{array}{c}\text { Pengawas } \\
\text { batu bara }\end{array}$ & 8 bulan \\
\hline
\end{tabular}

Tabel 2. Data tenaga kerja lokal yang menjadi informan

\begin{tabular}{ccccc}
\multicolumn{5}{c}{ menjadi informan } \\
\hline No & Nama & Asal & Usia & Pekerjaan \\
\hline 1 & Anna & Kendari & $\begin{array}{c}28 \\
\text { Tahun }\end{array}$ & $\begin{array}{c}\text { Admin } \\
\text { transportasi }\end{array}$ \\
\hline 2 & Akbar & Kolaka & $\begin{array}{c}30 \\
\text { Tahun }\end{array}$ & Admin finance \\
\hline 3 & $\begin{array}{c}\text { Hery } \\
\text { Agustian }\end{array}$ & Morosi & $\begin{array}{c}24 \\
\text { Tahun }\end{array}$ & $\begin{array}{c}\text { Helper } \\
\text { Operator }\end{array}$ \\
\hline
\end{tabular}

Sumber: Hasil penelitian,2019

\section{Mendeteksi akar permasalahan: Prasangka dan kecemburuan sosial Perbedaan bahasa}

Perbedaan bahasa merupakan salah satu faktor yang menyebabkan kurang efektifnya interaksi yang terjadi dalam komunikasi lintas budaya. Kurangnya pemahaman mengenai bahasa yang berbeda dapat menimbulkan kesalahpahaman dan perasaan tidak nyaman, dan akibat kesalahpahaman tersebut memunculkan konflik-konflik diantara sejumlah individu ataupun kelompok. Sesuai oleh penuturan beberapa informan berikut ketika ditanyakan mengenai apakah sering terjadi konflik atau apakah informan pernah mengalami konflik di lingkungan kerja?

Mr. Chang menuturkan bahwa:

"Selama bekerja disini kurang lebih dua tahun, saya pernah mengalaminya yakni konflik dengan tenaga kerja lokal. Waktu itu saya menegur salah satu tenaga kerja lokal yang di divisi saya karena tugas saya sebagai pengawas maka saya menegurnya tentunya menggunakan bahasa saya, saya menegurnya dengan baik-baik tapi dia membalas seperti marah dengan logat bicara yang cepat dan saya juga dengan nada bicara yang keras sehingga kami sempat saling diamankan security karena ribut". (Wawancara 2 Desember 2019).

Selain itu Informan Mr. Tsun juga menambahkan bahwa:

"Dalam bekerja memang penting interaksi agar tidak terjadi salah paham, saya bekerja disini sudah bertahun-tahun dan masalah yang saya lihat sering terjadi antara teman-teman kerja baik kami yang dari China maupun mereka yang tenaga kerja lokal, permasalahan mendasar itu selalu karena perbedaan bahasa yang menimbulkan konflik karena salah paham atau salah persepsi sehingga sering ribut". (Wawancara 6 Desember 2019).

\section{Perbedaan Budaya}

Budaya berkenan dengan cara manusia hidup, Manusia belajar berpikir, merasa, memercayai dan mengusahakan apa yang patut menurut budayanya. Adanya beberapa perbedaan karakter baik fisik maupun non fisik antara tenaga kerja China dan tenaga kerja lokal tersebut mulai dari perbedaan bahasa, cuaca, makanan, lingkungan, nilai-nilai yang berbeda, kebudayaan serta topografi wilayah tentunya akan

SSN: 2355-0287, E-ISSN: 2549-3299 
menimbulkan keterkejutan budaya terhadap tenaga kerja asing tersebut.

Berikut pemaparan salah satu Informan dalam perbedaan budaya yang mereka hadapi setelah memasuki lingkungan baru di PT. Virtue Dragon Nickel Industri.

Jiang Lili menuturkan bahwa:

"Saya merasa tidak nyaman dengan budaya orang disini ketika orang-orang yang dia baru kenal atau tidak kenal mempertanyakan hal yang sama dan beulang-ulang tentang masalah pribadi saya, pernah suatu hari saya mengingatkan seseorang pekerja lokal untuk tidak menanyakan hal yang sama berulang-ulang". (Wawancara 27 November 2019).

Jiang lili menambahkan juga:

"Jika ini membuat masalah yang terlalu masuk ke ranah pribadi saya sehingga saya tidak menyukainya, mereka bilang ini bentuk keramahan nya tapi menurut saya berlebihan karena hal yang privat di pertanyakan berulang, jika ini dilakukan berulang bisa saja ini akan membuat masalah dan ini berpotensi menjadi konflik personal karena saya tidak nyaman akan itu". (Wawancara 27 November 2019).

Mr. Tsun mengatakan hal yang sama juga tentang perbedaan budaya, dia mengatakan bahwa:

"Bekerja disini yang selalu menjadi masalah yaitu budaya kerja orang-orang disini yang terkesan lambat dan santai, sehingga saat kerja kadang kami mengalami ketidaknyamanan dan saling menyalahkan. Orang disini kadang saat bekerja mereka bercerita bersama rekan nya padahal itu bisa membahayakan nya (Tidak safety), dan jika ditegur mereka tenaga kerja lokal bisa tersinggung dan berbuntut panjang”. (Wawancara 5 Desember 2019).

\section{Kecemburuan sosial}

Kecemburuan sosial merupakan hal yang akan hadir jika didalam organisasi maupun perusahaan memiliki banyak anggota maupun karyawan yang berbeda latar belakang budaya nya. Seperti yang dipaparkan beberapa Informan berikut: Ibu anna mengatakan:

"Yang selalu mereka persoalkan itu kayak penempatan jabatan yang mayoritas jabatan yang strategis itu di isi tenaga kerja China, tentang gaji juga selalu jadi bahan protes nya tenaga kerja lokal disini”. (Wawancara 20 November 2019).

Hery agustian menambahkan:

"Saya sebagai helper disini, masuk pagi pulang sore pakaian penuhmi dengan oli mesin tapi gajita tidak sebanding dengan kerjaanta, tapi mau bagaimana lagi sudah begitumi resiko nya kita kerja. Kalau kita lihat jabatan disini memang ratarata orang China yang pegang jabatan yang bagus tapi tidak semua ada juga sebagian orang Indonesia tapi mayoritas orang China yang pegang, mau bagaimana lagi nah yang punya perusahaan memang orang China kita hanya tameng disini". (Wawancara 21 November 2019).

Dari pemaparan para informan tersebut maka kita bisa disimpulkan jika faktor utama dalam permasalahan yang selalu menjadi konflik antara tenaga kerja China dan tenaga kerja lokal ialah perbedaan bahasa, perbedaan budaya, dan kecemburuan sosial.

\section{PEMBAHASAN}

Dari temuan peneliti dan hasil wawancara dengan informan yang menjadi penyebab hadirnya prasangka dan kecemburuan sosial antara pekerja China dan pekerja lokal yang pertama adalah Stereotype budaya. Stereotype budaya menjadi momok yang menjadi faktor penyebab konflik. Dasar nilai

SSN: 2355-0287, E-ISSN: 2549-3299 
pemikiran yang telah tumbuh dan menjadi dasar mereka berpikir yang membentuk persepsi antara pekerja China dan pekerja lokal dalam berinteraksi sehingga membuat interaksi tidak harmonis karena telah membuat seakan-akan antara etnis ke etnis yang lain saling membenci membuat keadaan antara pekerja China dan pekerja lokal tidak harmonis di lingkungan dimana mereka berinteraksi.

Pandangan pekerja lokal yang telah menjadi dasar penilaian mereka saat berinteraksi yaitu mereka beraggapan jika pekerja China itu kasar dalam cara menyampaikan pesan saat bekerja dan suka banyak menyuruh pada saat bekerja. Sedangkan pekerja China juga beranggapan jika pekerja pekerja lokal sangat santai dan cepat marah jika di tegur dalam hal pekerjaan. Dari kedua pandangan tersebut antara tenaga kerja China dan tenaga kerja lokal memicu terjadinya konflik. Stereotype budaya yang mereka dapatkan saat di lingkungan kerja antara tenaga kerja China dan tenaga kerja lokal seperti halnya satu etnis membenci etnis lain karena stereotype tertentu yang dikonstrusikan secara sosial oleh etnis itu sendiri. Seperti yang terjadi dalam budaya kerja pekerja China yang tidak disukai oleh tenaga kerja lokal yakni saat kerja berbicara keras dan seenaknya menyuruh, hal tersebut membuat tenaga kerja lokal mempunyai stereotype kepada etnis China semuanya memiliki budaya kerja seperti itu. Begitu juga sebaliknya bagaimana pekerja China tidak menyukai budaya kerja lokal yang cara kerja nya sangat lambat, santai dan banyak mengobrol hal tersebut memicu hadirnya stereotype dalam pekerja China jika pekerja lokal mayoritas seperti itu. Akibat dari munculnya stereotype tersebut maka mereka akan saling membenci dan akan mudah berkonflik.

Stereotype budaya bisa disebut sebagai motor dari kekerasan struktural dan langsung. Karena sifat budaya bisa muncul pada dua tipe kekerasan tersebut. Kekerasan budaya (cultural violence) dilihat sebagai sumber lain dari tipe-tipe konflik melalui produksi kebencian, ketakutan, dan kecurigaan. Sumber kekerasan budaya ini bisa berangkat dari etnisitas, agama, maupun ideologi. Galtung menekankan makna kekerasan budaya ia maksud bukanlah hendak menyebut kebudayaan sebagai keseluruhan sistemnya melainkan aspekaspek dari kebudayaan itu. Galtung memberi definisi pada kekerasan budaya: "kekerasan budaya adalah aspek-aspek dari kebudayaan, ruang simbolis dari keberadaan masyarakat manusia dicontohkan oleh agama ideologi, bahasa dan seni, ilmu pengetahuan empiris dan formal (logis, matematis) yang bisa digunakan untuk menjustifikasi atau melegitimasi kekerasan struktural dan langsung" (Galtung 1990) Dalam (Susan, 2009).

Tenaga kerja China dan tenaga kerja lokal memiliki perbedaan karakter baik fisik, nonfisik, juga latar belakang budaya. Sehingga mengakibatkan ketidakcocokan dan membuat adaptasi mereka memiliki hambatan antara tenaga kerja China dan tenaga kerja lokal, awal kedatangan tenaga kerja China rata-rata mengalami kecemasan akan bahasa maupun perbedaan budaya, Hal tersebut sesuai dengan teori manajemen kecemasan dan ketidakpastian yang dikemukakan oleh William Gudykunst dalam (M.A, 2009) yang mengemukakan bahwa setiap orang yang menjadi anggota suatu kebudayaan tertentu akan berupaya mengurangi ketidakpastian pada tahap awal hubungan mereka, namun mereka melakukannya dengan cara yang berbeda-beda berdasarkan latar belakang budayanya.

Kedua, yang menjadi penyebab hadirnya prasangka dan kecemburuan sosial yakni akibat tidak meratanya upah antara tenaga kerja lokal dan upah tenaga kerja China, selain faktor upah yang tidak merata yang menyebabkan munculnya kecemburuan sosial juga yakni masalah penempatan jabatan strategis yang ditepati tenaga kerja

SSN: 2355-0287, E-ISSN: 2549-3299 
China dalam perusahaan. Hal tersebut memicu hadirnya kecemburuan sosial dikalangan masyarakat lokal maupun tenaga kerja lokal terhadap tenaga kerja China yang mengakibatkan terbentuknya prasangka dan stereotype yang tidak baik terhadap tenaga kerja China.

Adanya prasangka dikalangan masyarakat maupun tenaga kerja lokal yang beranggapan jika tenaga kerja lokal dalam perusahaan tersebut hanyalah tameng dan tenaga kerja lokal merasa jika keberadaan mereka dalam perusahaan seperti di kelas dua kan dalam tatanan sosial kerja di perusahaan. Sedangkan dalam masyarakat ataupun tenaga kerja lokal nya telah tumbuh dalam stereotype mereka jika seharusnya mereka sebagai tenaga kerja lokal asli dari daerah tersebut harusnya memiliki jabatan dan upah mumpuni jika kerja dalam perusahaan yang berlokasi dalam daerah mereka. Hal tersebut yang selalu menjadi persoalan sehingga selalu berujung konflik karena tuntutan masyarakat maupun tenaga kerja lokal tidak terpenuhi.

Secara teoritis menurut Johan Galtung, konflik bisa terjadi karena adanya kontradiksi atau ketidakcocokan yang mempengaruhi sikap sehingga mengubah atau mendorong seseorang/kelompok untuk berperilaku (Galtung, 1990). Saat tenaga kerja China dan tenaga kerja lokal mengalami perbedaan bahasa, perbedaan budaya, dan kecemburuan sosial saat proses adaptasi maupun interaksi maka hal ini akan menimbulkan kesalahpahaman yang menjadikan ini kontradiksi dan menjadikan tenaga kerja china dan tenaga kerja lokal menentukan bagaimana bersikap setelah mengalami kontradiksi dan mendorong mereka untuk berperilaku.

\section{Kesimpulan}

Berdasarkan hasil analisis dan pembahasan yang telah dikemukakan maka penulis menyimpulkan penyebab hadirnya prasangka dan kecemburuan sosial sebagai berikut:
1. Stereotype budaya negative yang telah menjadi dasar pemikiran masyarakat lokal untuk berinteraksi dengan pekerja China menjadi pemicu terjadi nya konflik antara pekerja China dan masyarakat lokal

2. Adanya ketidak berimbangan gaji dan dominan pekerja china yang memiliki jabatan di dalam perusahaan telah memicu hadirnya kecemburuan sosial sehingga sering menjadi penyebab konflik.

\section{REFERENSI}

Alo liliweri. (2001). Gatra-gatra Komunikasi Antar Budaya. Yogyakarta: Pustaka Pelajar.

Cangara, H. (2002). Pengantar Ilmu Komunikasi (Cetakan Keempat). In Jakarta: $P T$ Rajagrafindo Persada.

Chaplin, J. P. (2004). Kamus Lengkap Psikologi. Jakarta: PT. Raja Grafindo Persada.

Galtung, J. (1969). Violence, peace, and peace research. Journal of Peace Research. https://doi.org/10.1177/002234336 900600301

Galtung, J. (1990). Cultural Violence. Journal of Peace Research. https://doi.org/10.1177/002234339 0027003005

Kriyantono, R. (2006). Teknik Praktis Riset komunikasi - Rachmat Kriyantono, S.Sos., M.Si - Google Books.

Lippmann, W. (2017). Public opinion. In Public Opinion. https://doi.org/10.4324/978131512 7736

Littlejohn, S. W., \& Foss, K. A. (2009). Encyclopaedia of Theory. In Encyclopedia of Communication Theory. https://doi.org/10.1007/s13398014-0173-7.2

M.A, M. (2009). Teori Komunikasi Organisasi. Bandung: Ghalia 
Indonesia.

Miles, M. B., \& Huberman, ;A Michael. (1992). An Expanded Sourcebook Qualitative Data Analysis. Archives of Gynecology and Obstetrics. https://doi.org/10.1007/BF0275991 3

Mulyana, D., \& Rakhmat, J. (2010). Komunikasi antarbudaya. In Penantar Komunikasi antarbudaya.

Putra, P. A. (2009). Meretas Perdamaian Dalam Konflik Pilkada Langsung. Yogyakarta: Gava Media.

Soerjono Soekanto. (2006). Sosiologi Suatu Pengantar. Jakarta: Raja Grapindo Persada.

Sugiyono. (2011). Variabel Bebas. Metode Penelitian Kuantitatif, Kualitatif, Dan $R \& D$.

Susan, N. (2009). Pengantar Sosiologi Konflik (Edisi revi). Jakarta: Prenadamedia group.

William B. Gudykunst, Young Yun Kim (eds.): Methods for Intercultural Communication Research, International and Intercultural Communica tion Annual, Vol. 7. (1985). Organization Studies. https://doi.org/10.1177/017084068 500600319

\section{BIODATA PENULIS}

\section{Aldilal, S.I.K., M.I.KOM}

Studi S-1 (Sarjana) pada program Studi Ilmu komunikasi Universitas Haluole dan melanjutkan dan menyelesaikan studi S2 (Magister) pada Program Studi Ilmu Komunikasi Universitas Hasanuddin.

Prof. Dr. Andi Alimuddin Unde, M.Si Guru besar dan dosen tetap di Departemen Ilmu Komunikasi, Universitas Hasanuddin.

Dr. Jeanny Maria Fatimah, M.Si

Dosen tetap Departemen Ilmu komunikasi, Universitas Hasanuddin. 